\title{
Preface: Whose Abbey Theatre?
}

To whom did the Abbey Theatre belong? At various times, many of the Irish people involved in its life thought they had a right to call the Abbey "our Irish theatre": those who started the Irish National Dramatic Society, those who acted in it, those who wrote plays for it, those with a need or use for it, with a wish to make Ireland free, Gaelic, socialist, or feudal. In a legal sense, there can be no question that during its formative years, from 1904 to 1911, the Abbey Theatre belonged to no Irishman at all; it was the property of Annie E. F. Horniman, a middle-aged, middle-class dissenting London spinster. But now it is most often understood to be, as W. B. Yeats tried to make it then, an authors' theatre, even Yeats's very own theatre. To read through the essays of Yeats, one would think that the patron of the Abbey Theatre, Annie Horniman, had little effect on what was written and performed; that the actors were instruments of the will of the authors; and that the audience was unappreciative of the emergence of great literature before them, when not violently opposed to it. This book, in a study of Irish dramatic movements from 1899 to 1911, challenges that view of the theatre; it reevaluates the importance of authors, patrons, actors, and audience in shaping the literature of the stage.

It was Yeats's ambition-both in the Irish Literary Theatre (1899-1901) and in the Irish National Theatre Society that succeeded it - to found a literary theatre in Ireland over which the authors had control. Due largely to his efforts, Yeats, Lady Gregory, and J. M. Synge became the Board of Directors of the fully subsidized Irish National Theatre Society, Ltd., working rent-free out of the Abbey Theatre in Dublin. The First 
Principle of the Irish National Theatre Society, as stated by Yeats in the September 1903 issue of its house journal Samhain, was to "restore words to their sovereignty" on stage. ${ }^{1}$ The second, third, and fourth principles of the INTS follow from this preeminence of the author: the author comes before text, the text before the actor, the actor before the scene, and the audience (if it comes at all) comes last. Nothing must be permitted to rival in importance the author's words as spoken on stage. The sovereignty of the author, Yeats says, is essential because "Literature is always personal, always one man's vision of the world"; $;$ the rightness of the author's rule is self-evident: "Literature is always justified and needs no justification."

Later in this book, I discuss the social basis of Yeats's individualism and the political determination of his apolitical idea of theatre, but in itself there is nothing uncommon about Yeats's view of literature. Such pronouncements in his essays on dramatic literature are remarkable for their eloquence, not their originality. They take their place in a historical development in which claims for art have become grander with the gradual creation of an elite group of artists, connoisseurs, and critics. In this process, the work of literature has been assigned special status by marking it off from all other types of lettered knowledge, emptying it of utilitarian values, and freeing it at last from its age, place, and even its author. ${ }^{3}$ "'Literature' rises to value," as Frank Lentricchia puts it, "by a process of negation," by "a marked disposition to suppress its material conditions." ${ }^{4}$ Scholars can suppress such conditions simply by ignoring them, or balkanizing them in prefaces, appendices, and footnotes; in the theatre, Yeats sought to do this by political and economic control.

1. WBY, "The Reform of the Theatre," Samhain, September 1903 (Dublin: Sealy Bryers \& Walker \& T. Fisher Unwin), 9; id., Explorations (New York: Macmillan, 1962), 108.

2. WBY, "An Irish National Theatre," in Explorations, 115.

3. See Raymond Williams, Keywords: A Vocabulary of Culture and Society (New York: Oxford University Press, 1976), 15off.

4. Frank Lentricchia, Criticism and Social Change (Chicago: University of Chicago, 1983), 125. 
There is an unquestionable element of truth to the claim that authors and the language in which they embody their individual visions of "beauty and truth" are a necessary condition of literature. However, we have broadened our understanding of literature since the period when the stock conceptions of New Criticism prevailed, in which Literature, in a domain of pure freedom, was secreted from the soul of a great author and distilled in the tropes of a text, which then rose by its own virtue into the orderly formations of the canon, free of the conditions of its production. We are prepared to see that other factors must be considered as necessary to a fully sufficient definition of literature, including the ethics, politics, and rhetorical purposes of the author. ${ }^{5}$ Literature, however, arises not just from the author, but from the entire human struggle for power through articulation-more specifically, in the case of literature of the stage, from the actors who raise the text to life, the audiences in whom it takes shape, the patrons who foster it, and all the economic and political stresses in which it is lodged. Indeed, so great is the force of these authorizing conditions that while a definitive feature of a literary context is the text, there are richly significant theatrical events with no authorial text whatsoever.

One such event occurred in 1861 on the stage of the theatre that was to become the Abbey forty-three years later. It was

5. As Wayne Booth summarizes the critical situation, now freed of the ideologies of freedom, "We can . . . look at the ethics and politics that were concealed in the professedly anti-ethical and apolitical stances of modern aesthetic movements. We can question the notion, implicit in certain of those movements, that art is more important than people; that artists not only can but should ignore their audiences; that didactic and rhetorical interests are inherently non-aesthetic; that concern with ideologies and with truth or the practical value of art is a sure mark of its enemies; . . . that any true art work must be above politics" ("Freedom of Interpretation," in The Politics of Interpretation, ed. W. J. T. Mitchell [Chicago: University of Chicago Press, 1982], 55). Booth is concerned with the politics of those who write, those who first received, and those who now interpret texts. My own interests, while including these concerns, extend as well to the political forces that are actually constitutive of the works themselves. 
the most popular and politically effective matinee and evening show ever put on that stage. This was the funeral of Terence Bellew MacManus. ${ }^{6}$ After a brief part in a minor uprising, "The Rebellion of 1848 ," MacManus was tried, convicted, and sentenced to be transported to Van Diemen's Land (now Tasmania). He escaped after three years to San Francisco, where he quietly lived out his final ten years. After he was buried, local Irish-Americans came up with an idea: to dig up the body of Terence MacManus and send him home for a grand republican burial in Glasnevin cemetery, right under the noses of the British authorities. Joseph Mahoney and Michael Doheny of the New York branch of the Fenians promoted the idea and took up the collection of funds; James Stephens, the Irish Fenian chief, eventually seized control of the plan to transport the body of MacManus 6,000 miles on a three-month journey, across the United States by train, by ship to Cobh, again by train to Limerick Junction, and then on to Dublin, where he would lie in state at the Pro-Cathedral, Dublin's largest Catholic church. Both the British authorities and the Catholic Church opposed honoring violent revolutionaries or tolerating Fenian demonstrations disguised as funeral rites, so the body, barred from the ProCathedral, was placed instead on the stage of the Mechanics' Institute in Abbey Street. Thousands entered its doors, witnessed the scene on stage, and departed with fairly precise knowledge of what the performance said. Its speech was eloquent by virtue of the view the audience took of the scene: a reverent gaze at proof that Irishmen suffer under British rule, that they fight against it, that they die for the struggle, that, finally, they are honored for their sacrifice. Collectively, the audience witnessed a generational bond tying together Irish revolutions, renewed through past failures. The muteness of the testimony was its power and clarity.

This scene, clearly, had no text. There were, however, a host of authorizing conditions: Captain John Smith conceived the

6. Oliver MacDonagh, States of Mind: A Study of Anglo-Irish Conflict, 1790-1980 (London: George Allen \& Unwin, 1983), 84-85. 
idea, Mahoney and Doheny promoted it, and James Stephens openly defied the clergy, roused the audience, and wrote the graveside address, a sonorous interpretation of the meaning of what had already happened in the theatre on Abbey Street. Without their collaborative authorship, there would have been no theatrical event. However, there were still further authorizing conditions. Four men can at any time decide to disinter a body in one country, transport it to another, leave it lying on a stage, and then reinter it, without any such import at all. To create the significance of "The Last Appearance of Terence Bellew MacManus," it was necessary to have a people who look backward in times of trouble, who have important funeral customs, who for political reasons venerate (and create at need) national martyrs, and who respond quickly to orders from secret and alternative forms of power. These factors were essential to the significance of the event; without them, the Fenian leaders would never have gotten 50,000 people to march in the Dublin funeral cortege. The authorship of "The Last Appearance of Terence Bellew MacManus" consists in the Fenians' conception of how the event would be read and in the conspiracy of the Irish masses to read it as meaningful.

Not only did the event have its authorship (organizational and communal), it also had other elements of dramatic performance, such as an actor. MacManus at the time of his death was an unsuccessful San Francisco businessman; at his height of glory, he was only a minor figure in a civil disturbance requiring the attention of the local constabulary. On stage, however, he was cast in the role of martyred hero. Although there are plays by Beckett with very nearly as little dialogue and action, and hardly so much impact, the 1861 spectacle of the disinterred rebel was not a play. Staged event, enactment of an idea, propaganda ploy, performance with authors, an actor, publicity, audience, and reviews, it may have been all of these, but it was not a play because the body on stage was indeed the corpse of Terence MacManus. Of course, we can posit counterfactual conditions for such an event becoming a play: an author beforehand owns up to an intention to engage the audience's interpretative abilities; he 
xviii

asks them to suppose that a motionless actor is a corpse, or that a corpse is the last remains of Terence MacManus; the audience, consequently, approaches the scene on stage with the special sort of attention one grants to fictive events. Although the same arrangement on stage could serve as a play, there would, in short, have had to be a symbolic substitution for reality, and some rearrangement of intentions and expectations, for the 9 November 1861 spectacle at the Mechanic's Institute to be counted as the first and greatest moment in Irish National Theatre.

The point of this illustration is that while the existence of author and text are by definition essential to dramatic literature, the other factors that figure in making a publicly staged event significant-the promotion, the nature of the fund-raising, the political context, the predisposition of the audience, the character of the actor, the meaning of the scene, the commentary upon the event-are so important that one may discover something very much like an authorless, textless play. These other factors do not cease to be important when there is an author and a text; they continue to be the very stuff of significance. These nutritive, sustaining conditions of literary production can only be suppressed by suppressing the significance of the text as well.

While it is not precisely true to say that this book is about all but the text, its emphasis is obviously not upon textual criticism of the plays of the early Abbey Theatre, either as pieces to be revived for the modern stage or as texts to be appreciated for their formal integrity; it does not aim to show that this play by Yeats is overrated, that one by Lady Gregory underrated, or Synge's Playboy justly prized. There are many books offering expert appreciations of this literature, and there will be more such books still, the authors of the Revival having established an enduring claim upon our interest. ${ }^{7}$ This

7. Among the critics who have made the strongest claims for the value of Yeats's plays are David R. Clark, who persuasively connects late plays such as Purgatory with the dramas of Beckett in W. B. Yeats and the Theatre of Desolate Reality (Dublin: Dolmen Press, 1965); James W. Flannery, who argues that 
book is less about my appreciation of plays by Yeats, Synge, and others than about the reception of a few of those plays by Dublin audiences from 1899 to 1910 . More completely, the aim here is to restore the traditional text to its historical moment, and, in the phrases of Lentricchia's call to contemporary critics, to bring to light "its politically activist, materially textured substance" "in an act of reading that penetrates the idealist myths . . . that have veiled the text's real involvement in the human struggle. ${ }^{8}$ No matter what the nature of that involvement, it is not to be passed over, explained away, or excused, as if such matters, being "reductionist," detract from the author and the plays. One need not prove a writer a secular saint in order to preserve for him or her the title of a great writer, although those who of all the millions of speakers of a language have used it to best effect, those whose force of utterance puts them in a league of their own, and to whom we are drawn as crowds to star performers, may seem to merit any honor we grant them. Yeats, certainly, was one such writer: he came early into his force, words obeyed his call, and he mounted up in an ascendancy over his audience; he was indeed, as he bragged to his sister, King of the Cats. But even in his own time, when audiences found a few of his early pieces for the stage less than entertaining, dramatically ineffective, or even thematically repellant, no one questioned

Yeats's developing theories of the stage anticipate the ideas of Total Theatre in W. B. Yeats and the Idea of a Theatre: The Early Abbey Theatre in Theory and Practice (New Haven: Yale University Press, 1976); Katharine Worth, who relates the plays of Yeats to those of Maeterlinck, and to international modernist drama in general, in The Irish Drama of Europe from Yeats to Beckett (Atlantic Highlands, N.J.: Humanities Press, 1978); and, finally, Andrew Carpenter, who aims to make the best possible case for each of Yeats's plays as vehicles for the stage in The Dramatic Imagination of W. B. Yeats (Dublin: Gill \& Macmillan, 1978). This book differs from theirs in scope (since it does not include the late plays or all of the early ones), in focus (it includes plays by many Abbey authors), and, most important, in purpose. Since they and other scholars have so ably done their work, we may now assume the interest of Yeats's plays to have been established, and need not arrange our remarks as a justification of Yeats the playwright.

8. Lentricchia, Criticism and Social Change, 142. 
that Yeats's plays were works of a master's hand. ${ }^{9}$ In short, Irish audiences awarded him the laurel, but refused him a halo; and while complaining that some plays by Yeats or Synge did not belong in the National Theatre, they did not doubt their honored place in the National Library. So the literary quality of the Abbey authors was not in question then, and, a fortiori, it need not be the main issue here. A book that concentrates, not on proving that the plays are works of art, but on showing their considerable political craftiness and social meaning is unlikely to diminish their claims upon our attention. Indeed, one may hope that when these works are fully restored to their context, they cannot be regarded as merely literary, altogether too lofty, or positively hermetic; rather they will appear as freighted with authorial purpose, alive with social suggestion, and dangerous in the intimate violence they harbor against the predispositions of the audience.

In the chapters that follow, instead of writing a chronicle of the Irish Literary Renaissance, or a theoretical analysis of literary production, I have often chosen to take as points of departure (or, in some cases, destination) the first performance of a play by Yeats, Synge, or Lady Gregory. The events of the opening night of The Countess Cathleen, The King's Threshold, In the Shadow of the Glen, On Baile's Strand, Dervogilla, or The Playboy of the Western World-what happened with actors, spectators, writers, reviewers, and patrons-are samples of "the materially textured substance" of "the traditional text" that must as a whole be the subject of a reading. The readings in individual chapters, however, are guided toward different theoretical concerns. Chapter 1 , on The Countess Cathleen, is a general introduction to all those discursive forces around the play that make the meaning of the play. Chapter 2, on Yeats's

9. This characterization of the audiences' judgment of Yeats's early plays is not meant to apply to all those who attended or equally to all plays. Cathleen ni Houlihan (co-authored with Lady Gregory), for instance, was universally admired by nationalists; Deirdre had a good run with Mrs. Patrick Campbell in the lead; and On Baile's Strand was spared adverse reviews. The full complexity of the reception of Abbey plays is addressed below. 
early role in the Irish National Theatre Society, is a critique of claims for the autonomy and freedom of the author in the theatre. The third chapter concentrates on the role of the audience; the fourth on the role of the actors; the fifth on the patron, Annie Horniman. The final chapter is given to illustrating that the political perspective is, to borrow Fredric Jameson's phrase, "the absolute horizon of all reading and interpretation." 10

This type of study would not be possible in the case of some literary periods; the documentary evidence of the "materially textured substance" of history would not be available. The figures involved in the Irish Literary Renaissance lived, however, in an era neither so long past that their communications have been lost nor so recent that they relied on the telephone. Those at the Abbey knew, even as they planned, that they were nation-building, that what they made was history; as a result, they recorded every day in the light of the age and kept nearly every scrip of the multitudinous record. Furthermore, the heroic and scrupulous industry of scholars has made the letters and lives of all the participants, major and minor, available to readers. Few authors have been so well served as these Irish writers were by Richard Finneran, George Mills Harper, Robert Hogan, John Kelly, James Kilroy, William M. Murphy, Ann Saddlemyer, and many others who receive but a poor acknowledgment of their service in the notes and bibliography. Had they not done their work first, and done it so splendidly, I would still be at the National Library of Ireland, the New York Public Library, or another of the many institutions with Irish archives, ruining my eyes over the cursive of Yeats, with no hope of finishing this book for years to come, perhaps without even a glimpse of its picture of the totality of forces around the text.

10. Fredric Jameson, The Political Unconscious: Narrative as a Socially Symbolic Act (Ithaca, N.Y.: Cornell University Press, 1981), 17. 
